\title{
ANALISIS FAKTOR-FAKTOR YANG BERPENGARUH PADA MINAT BERWIRAUSAHA MAHASISWA
}

\author{
Noormalita Primandaru \\ STIE YKPN, Indonesia \\ Email: Noormalita90@gmail.com
}

\begin{abstract}
Abstrak: Analisis Faktor-Faktor yang Berpengaruh pada Minat Berwirausaha Mahasiswa. Salah satu alternatif untuk memecahkan masalah pengangguran adalah dengan memberdayakan kelompok terdidik melalui program kewirausahaan di perguruan tinggi yang diharapkan mampu berkontribusi dalam penyerapan tenaga kerja sehingga mengurangi pengangguran dan beban negara. Penelitian ini menguji model yang bertujuan untuk mengetahui pengaruh internal locus of control, social support dan need for achievement terhadap minat berwirausaha pada mahasiswa. Penelitian ini termasuk dalam kategori penelitian cross-sectional. Hasil penelitian menunjukkan bahwa terdapat pengaruh internal locus of control dan social support pada minat berwirausaha mahasiswa, terdapat pengaruh internal locus of control terhadap need for achievement mahasiswa, tidak terdapat pengaruh social support pada need for achievement dan yang terakhir terdapat pengaruh need for achievement terhadap minat berwirausaha mahasiswa.
\end{abstract}

Kata kunci: internal locus of control, social support, need for achievement, entrepreneurial intention

\begin{abstract}
The Factors Affecting the Entrepreneurial Intention of College Students. The alternative to solve an unemployment problem is to empower the educated person through entrepreneurship programs at colleges that are expected to contribute to employment, thereby reducing unemployment and the burden on the state. This study tested a model that aims to determine the influence of internal locus of control, social support and the need for achievement against in entrepreneurial intention of the student. This study was a cross-sectional. The results show a significant relationship between internal locus of control and social support to the entrepreneurial intention of students. There is a significant relationship between internal locus of control and the need for achievement of students. There is an insignificant relationship between social support and the need for achievement and the last there is a significant relationship between need for achievement and entrepreneurial intention of students.
\end{abstract}

Keywords: internal locus of control, social support, need for achievement, entrepreneurial intention

\section{PENDAHULUAN}

Saat ini menjadi penting untuk memperkenalkan kewirausahaan di kedua negara, yaitu negara maju dan berkembang (Ozaralli \& Rivenburgh, 2016). Di negara maju, seperti Amerika Serikat, kewirausahaan telah lama dianggap sebagai cara untuk memacu inovasi dan kemajuan teknologi, menimbulkan persaingan, dan menciptakan lapangan kerja, yang mengarah ke pertumbuhan ekonomi dan kesejahteraan nasional (Holmgren, 2005). Salah satu syarat suatu negara dapat menjadi negara maju adalah jika jumlah wirausahanya mencapai 
2\% dari jumlah populasi masyarakat. Indonesia sendiri baru memiliki 1,5\% wirausaha dari sekitar 252 juta penduduk, sehingga Indonesia masih membutuhkan sekitar 1,7 juta wirausaha untuk mencapai angka 2\%. Rata-rata penduduk di Indonesia memilih untuk menjadi pegawai daripada menjadi wirausaha (Loso, 2008)

Fenomena tersebut terjadi dikarenakan masih rendahnya motivasi dan minat masyarakat Indonesia. Jika pola pikir masyarakat tidak diubah maka Indonesia akan mempunyai banyak permasalahan, salah satunya adalah semakin menyempitnya lapangan pekerjaan, banyaknya kesempatan kerja dengan orang yang mencari kerja lebih banyak orang yang mencari kerja, sehingga banyak orang yang tidak mendapatkan pekerjaan yang mengakibatkan jumlah pengangguran khususnya pengangguran intelektual menjadi semakin besar serta berdampak pada kondisi perekonomian di Indonesia.

Suatu hal yang tak dapat dipungkiri bahwa Indonesia menghadapi masalah keterbatasan kesempatan kerja bagi para lulusan perguruan tinggi dengan semakin meningkatnya jumlah pengangguran intelektual belakangan ini. Data dari Badan Pusat Statistik Indonesia menyatakan bahwa jumlah pengangguran paling tinggi berasal dari lulusan Iulusan Perguruan Tinggi (Setiadi, 2008). Kondisi yang dihadapi akan semakin diperburuk dengan situasi persaingan global yaitu Masyarakat Ekonomi ASEAN (MEA) yang akan memperhadapkan lulusan perguruan tinggi Indonesia bersaing secara bebas dengan lulusan dari perguruan tinggi asing. Menurut Rasyidi dalam Ariamtisna (2008) banyaknya angka pengangguran disebabkan oleh minimnya jiwa kewirausahaan masyarakat. Kecenderungan menunjukkan bahwa semakin tinggi tingkat pendidikan semakin besar keinginan untuk mendapatkan pekerjaan yang aman.

Salah satu alternatif untuk memecahkan masalah pengangguran adalah dengan memberdayakan masyarakat dan kelompok terdidik melalui program kewirausahaan yang diharapkan mampu berkontribusi dalam penyerapan tenaga kerja sehingga mengurangi pengangguran dan beban negara (Adnyana \& Purnami, 2016). Menurut Rauch dan Frese (2000) bahwa faktor yang berkaitan dengan keberhasilan kewirausahaan salah satunya adalah internal locus of control. Hal tersebut didukung oleh penelitian yang dilakukan oleh Parsa (2011) bahwa internal locus of control menyumbang cukup tinggi terhadap keberhasilan kewirausahaan yakni sebesar $70 \%$. Selain internal locus of control, faktor yang mempengaruhi niat berwirausaha adalah social support dan need for achievement. Brockhaus (1980) \& McClelland (1965) dalam Hansemark (2003) internal locus of control dan need for achievement pada seseorang yang akan memulai usaha itu penting, karena dapat digunakan untuk mengetahui bagaimana karakteristik atau kekuatan seseorang sehingga dapat memprediksi perilaku kewirausahaan seseorang. Dewi (2010) menyatakan bahwa ada 2 (dua) faktor yang mempengaruhi minat berwirausaha mahasiswa yaitu faktor intrinsik dan faktor ekstrinsik. Faktor intrinsik terdiri dari perasaan dan emosi, pendapatan, motivasi dan cita-cita, dan harga diri. Sedangkan faktor ekstrinsik terdiri dari dukungan 
lingkungan keluarga, lingkungan masyarakat, peluang, dan pendidikan dan pengetahuan. Adler \& Kwon (2002) dalam Urban \& Teise (2015) berpendapat bahwa luasnya social support, dikonseptualisasikan sebagai konsep modal sosial, yang mencerminkan ikatan sosial (misalnya, persahabatan) yang dapat dijadikan untuk memotivasi tujuan (misalnya, dukungan moral dan material, pekerjaan, dan saran sosial). Dukungan untuk berwirausaha dapat berupa dukungan moril (kesempatan, kepercayaan, pemberian ide/ pemikiran), atau dukungan materiil dengan memberikan modal, penyediaan alat/ perlengkapan usaha atau lokasi/ tempat usaha.

Lambing dan Kuehl (2000) menyatakan bahwa tujuan yang ingin dicapai seorang wirausahawan dipengaruhi oleh kebutuhan akan berprestasinya yang mendorong individu untuk menghasilkan yang terbaik dan biasanya memiliki inisiatif serta keinginan yang kuat untuk mengungkapkan ide-ide dalam pikirannya, menyampaikan gagasan demi mencapai suatu kesuksesan. Sebuah niat diperlukan untuk langkah awal dalam memulai wirausaha. Niat adalah keinginan tertentu seseorang untuk melakukan sesuatu atau beberapa tindakan, itu merupakan hasil dari pikiran sadar yang mengarahkan tingkah laku seseorang (Parker, 2004 dalam Adnyana \& Purnami, 2016). Menurut Ramayah dan Harun (2005), niat berwirausaha didefinisikan sebagai tendensi keinginan individu untuk melakukan tindakan wirausaha dengan menciptakan produk baru melalui peluang bisnis dan pengambilan risiko. Kegiatan kewirausahaan sangat ditentukan oleh niat individu itu sendiri. Orang-orang tidak akan menjadi pengusaha secara tiba-tiba tanpa pemicu tertentu.

Berdasarkan latar belakang yang telah dipaparkan maka penelitian ini difokuskan untuk mengetahui pengaruh berbagai faktorfaktor yang mempengaruhi niat untuk berwirausaha pada mahasiswa STIE YKPN. Hasil penelitian ini diharapkan dapat menjadi masukan bagi pengembangan kerangka pembelajaran pendidikan kewirausahaan di perguruan tinggi dalam rangka mendorong munculnya sarjana yang memilih karir sebagai entrepreneur. Secara lebih detail beberapa tujuan yang ingin dicapai dari penelitian ini adalah (1) menganalisis pengaruh Internal locus of control terhadap minat berwirausaha pada mahasiswa STIE YKPN, (2) menganalisis pengaruh Internal locus of control terhadap need of achievement pada mahasiswa STIE YKPN, (3) menganalisis pengaruh social support terhadap minat berwirausaha pada mahasiswa STIE YKPN, (4) menganalisis pengaruh social support terhadap need of achievement pada mahasiswa STIE YKPN, (5) menganalisis pengaruh need for achievement terhadap niat berwirausaha pada mahasiswa STIE YKPN.

Konsep tentang internal locus of control pertama kali dikemukakan oleh Rotter (1966 dalam Hansemark, 2003) internal locus of control merupakan salah satu variabel kepribadian (personality), yang didefinisikan sebagai keyakinan individu terhadap mampu tidaknya mengontrol nasib (destiny) sendiri. Sedangkan internal locus of control menurut Kreitner dan Kinicki dalam (Wiriani, et al. 2013), terdiri dari dua konstruk yaitu internal dan eksternal, di mana internal locus of control apabila seseorang meyakini bahwa 
apa yang terjadi selalu berada dalam kontrolnya dan dia selalu mengambil peran serta bertanggung jawab dalam setiap pengambilan keputusan, sedangkan external locus of control apabila seseorang meyakini bahwa kejadian dalam hidupnya berada di luar kontrolnya. Menurut Forte (2005) internal locus of control mengacu pada kondisi-kondisi di mana seseorang mengatribusikan kesuksesan dan kegagalan mereka. Forte juga mengatakan bahwa ketika orang-orang mempersepsikan internal locus of control tersebut berada dalam dirinya sendiri, mereka akan menghasilkan pencapaian yang lebih besar dalam hidup mereka dikarenakan mereka merasa potensi mereka benar-benar dapat dimanfaatkan sehingga mereka menjadi lebih kreatif dan produktif.

Social support (dukungan sosial) didefinisikan oleh Gottlieb (dalam Smet 1994) sebagai informasi verbal dan non verbal, saran subjek di dalam lingkungan sosialnya atau yang berupa kehadiran dan berpengaruh pada tingkah laku penerimanya. Dalam hal ini orang yang memperoleh dukungan sosial merasa lega karena diperhatikan, mendapat saran atau kesan yang mendukung keinginannya. Salah satu faktor penting dalam berwirausaha adalah dukungan sosial. Dukungan sosial dapat berasal dari lingkungan sosial, antara lain teman, anggota keluarga, dan anggota kelompok atau komunitas (Taylor. et al, 1994). Kail (2000) memberi definisi dukungan sosial atau dukungan relasional sebagai suatu sumber yang bersifat emosi dan informasi atau pendampingan yang diberikan ke seseorang dari orang orang di sekitarnya untuk menyelesaikan masalah serta kondisi yang terjadi pada kehidupan seseorang tersebut.

Konsep need for achievement pertama kali oleh McClelland di akhir 1950-an dan awal 1960-an McClelland berpendapat bahwa Menurut McClelland seseorang yang memiliki kebutuhan prestasi yang tinggi akan memiliki keinginan yang kuat untuk mengerjakan tugas-tugas yang menantang, memiliki tanggung jawab yang besar terhadap tugas yang dikerjakan dan pada saat selesai dalam mengerjakan suatu pekerjaan, seseorang tersebut menginginkan umpan balik atau feedback. Seseorang dengan need for achievement yang tinggi memiliki keinginan kuat untuk sukses dan sebagai konsekuensinya akan memiliki perilaku entrepreneurial (McClelland, 1965 dalam Hansemark, 2003). Lebih lanjut menurut McCelland mendefinisikan need for achievement yaitu usaha untuk menjadi lebih baik, menjadi sukses dan merasa berkompeten, menurutnya need for achievement akan memberikan energi yang positif untuk bertindak atau berperilaku dengan percaya diri sesuai dengan situasi yang dihadapi. Need for achievement juga dapat diartikan sebagai keinginan untuk menyelesaikan suatu tugas dengan sasaran secara lebih efektif. Individu-individu yang mempunyai need for achievement yang tinggi cenderung menetapkan sasaran yang cukup sulit dan mengambil keputusan yang lebih beresiko (Grifffin \& Moorhead, 2013).

Menurut Katz \& Gartner dalam Indarti \& Rostiani (2008) intensi kewirausahaan diartikan sebagai proses pencarian informasi yang dapat digunakan untuk mencapai tujuan pembentukan suatu usaha. Intensi adalah harapan-harapan, keinginan- 


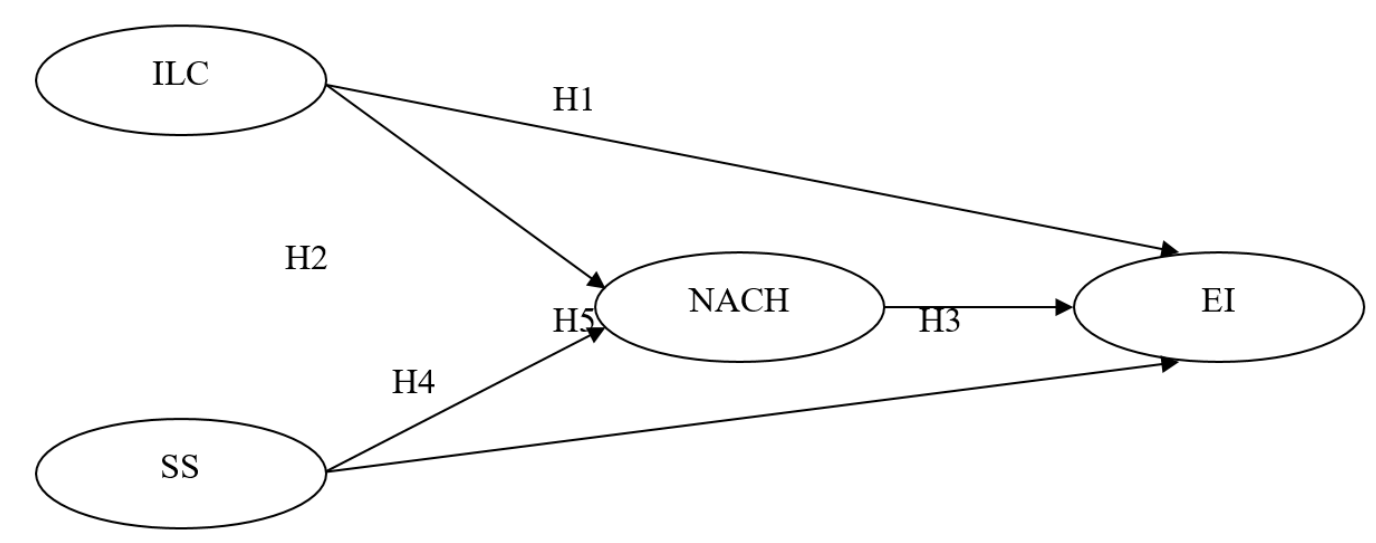

Gambar 1. Model Penelitian

Keterangan:

ILC : Internal locus of control

SS : Social support

$\mathrm{NACH}$ : Need for achievement

$\mathrm{EI} \quad$ : Entrepreneurial intention

keinginan, ambisi-ambisi, cita-cita, rencanarencana atau sesuatu yang harus diperjuangkan seseorang dimasa depan. Intensi berkaitan dengan indikasi akan seberapa susah seseorang mencoba untuk memahami, seberapa besar usaha seseorang dalam merencanakan sesuatu, untuk melakukan suatu perilaku tertentu (Hisrich, Peters \& Shepherd, 2010). Intensi memainkan peranan yang khas dalam mengarahkan tindakan, yaitu menghubungkan antara pertimbangan yang mendalam, diyakini dan diinginkan oleh seseorang dengan tindakan tertentu (Krueger \& Carsrud dalam Indarti dan Rostiani, 2008). Intensi telah menjadi prediktor terbaik bagi perilaku berwirausaha seseorang (Ajzen \& Fishbein dalam Kautonen \& Luoto, 2008).

\section{METODE}

Model analisis yang dilakukan dalam penelitian ini adalah model analisis Partial Least Square (PLS) mengikuti pola model persamaan struktural (SEM) berbasis varian yang secara stimultan dapat melakukan pengujian model pengukuran sekaligus pengujian model struktural. Untuk uji validitas dan reliabilitas peneliti menggunakan model pengukuran, sedangkan model struktural digunakan untuk uji kausalitas (pengujian hipotesis dengan model prediksi). Menurut Abdillah dan Jogiyanto (2009), PLS sebagai SEM berbasis varian dengan AMOS dan LISREL berbeda dengan PLS sebagai SEM berbasis varian kovarian. SEM berbasis varian bertujuan untuk memprediksi model untuk pengembangan teori, sedangkan SEM berbasis kovarian bertujuan untuk mengestimasi model untuk pengujian atau konfirmasi teori.

Penelitian ini termasuk dalam kategori penelitian cross-sectional, yaitu penelitian yang hanya mengambil data melalui penyebaran kuesioner hanya dalam satu saat saja dengan menggunakan desain survei sebagai teknik pengumpulan data yang 
bertujuan untuk memperoleh keterangan secara nyata melalui penggunaan kuesioner sebagai alat pengumpul data yang utama (Sekaran, 2006). Instrumen dalam penelitian ini mengadopsi instrumen penelitian yang telah dikembangkan oleh peneliti sebelumnya dimana semua jawaban dari pertanyaan akan diukur dalam lima skor dengan menggunakan skala ordinal 5 poin Likert, mulai dari sangat setuju (poin 5) sampai sangat tidak setuju (poin 1). Unit analisis penelitian ini adalah individu. Artinya responden penelitian yang menjadi sample mewakili dirinya sendiri.

Populasi yang menjadi subjek dalam penelitian ini adalah mahasiswa STIE YKPN. Sampel penelitian berjumlah 126 mahasiswa STIE YKPN yang mengambil mata kuliah kewirausahaan dan sedang menempuh semester enam (6). Jumlah sampel tersebut didasarkan pada lima kali estimated parameter (Hair. et al, 1998). Sehingga jumlah sampel minimal adalah $5 \times 20=100$. Namun dalam penelitian ini melibatkan 126 responden terpilih.

Dalam penelitian ini, teknik pengambilan sampel yang digunakan adalah non probability sampling tipe purposive sampling, yaitu teknik pengambilan sampel yang tidak memberi peluang/ kesempatan sama bagi setiap variabel atau anggota populasi untuk dipilih menjadi sampel (Sekaran, 2006). Data yang dipergunakan dalam penelitian ini berupa data primer yang diperoleh secara langsung dari responden dengan memberikan kuesioner yang akan diisi oleh reponden (Sekaran, 2006).

Pengujian statistik yang bertujuan untuk menguji efek prediksi antar variabel laten untuk melihat apakah ada hubungan atau pengaruh antarvariabel tersebut disebut dengan model prediksi. Penggunaan model prediksi ini memiliki konsekuensi tersendiri, yaitu pengujian dapat dilakukan tanpa dasar teori yang kuat, mengabaikan beberapa asumsi, dan parameter ketepatan model prediksi dilihat dari nilai koefisien determinasi $\left(R^{2}\right)$. Karena alasan inilah, model prediksi sangat tepat dilakukan pada penelitian yang bertujuan untuk mengembangkan teori.

Pengujian statistika yang bertujuan untuk mengestimasi model teoritikal yang dibangun dengan mengukur kelayakan model pada jenjang variabel laten dan parameter yang diestimasi atau indikatornya disebut dengan model estimasi. Sama seperti model prediksi, model estimasi juga memiliki konsekuensi tersendiri dalam penggunaannya. Konsekuensi penggunaan model estimasi adalah pengujian menuntut basis teori yang kuat, berbagai asumsi yang rigit, dan kelayakan model menjadi ukuran utama (goodness of fit model). Oleh karena itu, model estimasi ini sangat tepat digunakan untuk menguji teori dan mendapatkan justifikasi terhadap pengujian tersebut dengan serangkaian hasil statistika yang kompleks.

\section{HASIL DAN PEMBAHASAN}

Sejumlah 126 responden mengisi kuesioner penelitian ini. Komposisi responden didominasi oleh kelompok umur 20 - 24 tahun, $60 \%$ responden adalah wanita, seluruh responden telah menempuh mata kuliah kewirausahaan, dan sedang menempuh semester enam (6). Komposisi ini memperlihatkan bahwa sampel yang 


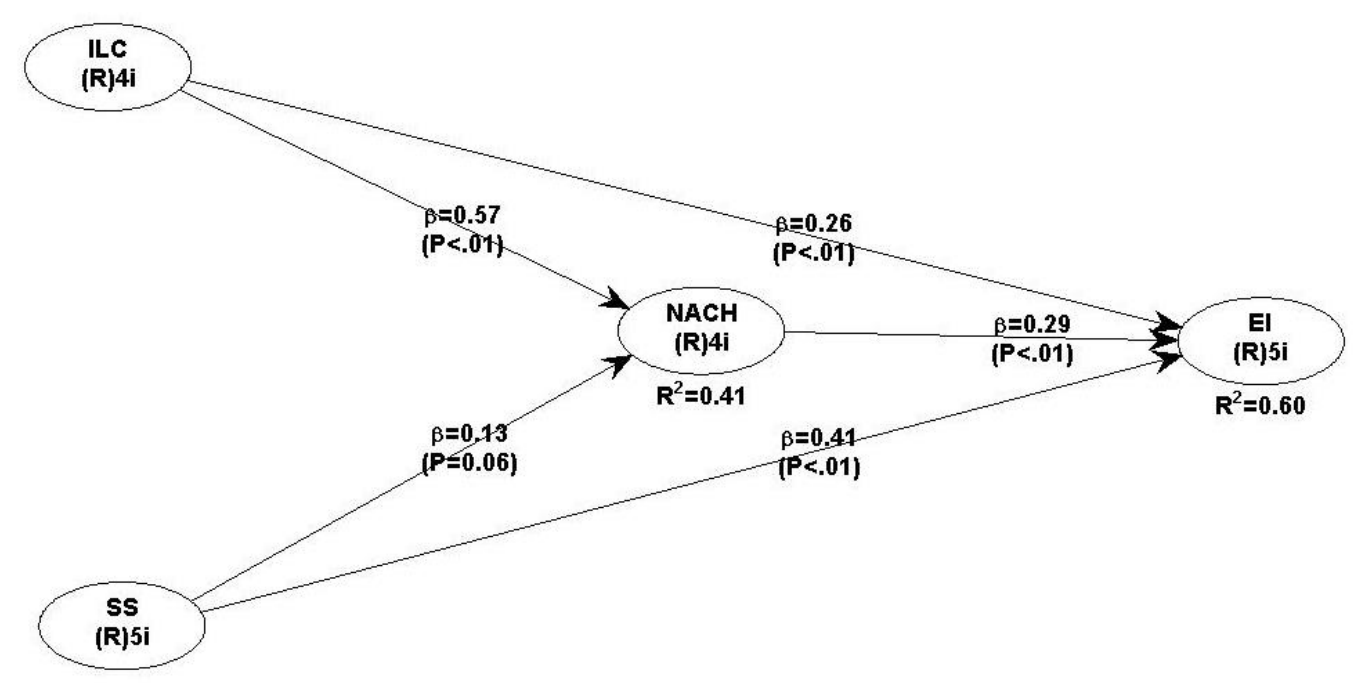

Gambar 2. Hasil Penelitian

menjadi responden adalah mahasiswa yang akan lulus sarjana.

Analisis induktif dengan menggunakan Partial Least Square (PLS) meliputi penelitian goodness of fit model (inner model), yang berfungsi ntuk mengetahui kecocokan suatu model yang digunakan dalam penelitian ini dengan menggunakan variabel internal locus of control, social support, need of achievement, dan minat berwirausaha. Hasil pengujian goodness of fit model dapat dilihat pada Tabel 1.

Tabel 1. Nilai goodness of fit model

\begin{tabular}{cc}
\hline APC $=0,335, P<0,001$ & Good if $P<0,05$ \\
\hline$A R S=0,503, P=0,001$ & Good if $P<0,05$ \\
\hline AVIF $=1,399$ & Good if $\leq 5$ \\
\hline
\end{tabular}

Berdasar hasil pengujian, nilai Average Path Coefficient (APC) sebesar 0,335 dengan nilai $p<0,001$, hal ini berarti nilai APC signifikan $(<0,05)$. Signifikannya nilai APC dapat membuktikan bahwa variabel endogen dan eksogen memiliki hubungan sebab dan akibat baik secara langsung maupun tidak langsung. Nilai Average R-squared (ARS) diperoleh hasil 0,503 dengan nilai $p=0,001$, hal ini berarti nilai ARS signifikan karena nilai $p<0,05$. Nilai 0,503 menunjukkan bahwa variabel pada penelitian ini hanya mampu mempengaruhi variabel dependen sebesar $50,3 \%$ dan 49,7\% dimiliki oleh variabel lain di luar model. Pada model penelitian ini tidak terjadi multikolinearitas, terbukti dari nilai Average Variance Inflation Factor (AVIF) sebesar 1,399 yang nilainya $\leq 5$.

Hasil korelasi antar konstruk diukur dengan melihat path coefficients dan tingkat signifikansinya yang kemudian dibandingkan dengan hipotesis penelitian. Tingkat signifikansi yang dipakai dalam penelitian ini adalah sebesar 5\%. Berikut merupakan gambar hasil penelitian dengan menggunakan teknik analisis data dengan menggunakan software WarpPLS 5.0.

Hipotesis pertama dalam penelitian ini adalah pengaruh internal locus of control terhadap minat berwirausaha pada mahasiswa STIE YKPN. Hasil penelitian menunjukkan bahwa nilai $\mathrm{P}<0,01$ dengan nilai signifikansi $5 \%$ hal tersebut menunjukkan bahwa variabel internal locus of control berpengaruh terhadap minat berwirausaha mahasiswa STIE YKPN Hasil ini 
didukung oleh penelitian yang dilakukan oleh Zain, Akram dan Ghani (2010) bahwa internal locus of control mempengaruhi secara langsung terhadap minat berwirausaha siswa di Malaysia, serta pengaruh trait ekonomi terhadap intensi berwirausaha siswa. Individu dengan internal locus of control bergantung pada mereka sendiri untuk memutuskan apa yang benar atau salah dan berkaitan dengan keberhasilan dalam berwirausaha (Forte, 2005). Mahasiswa yang mempunyai internal locus of control yang kuat biasanya percaya bahwa keberhasilan dalam meraih tujuan hidupnya bergantung pada tindakan atau keputusan yang mereka buat sendiri dalam berwirausaha.

Hipotesis kedua dalam penelitian ini adalah pengaruh internal locus of control terhadap need for achievement pada mahasiswa STIE YKPN. Hasil penelitian menunjukkan bahwa nilai $\mathrm{P}<0,01$ dengan nilai signifikansi $5 \%$ hal tersebut menunjukkan bahwa variabel internal locus of control berpengaruh terhadap variabel need for achievement mahasiswa STIE YKPN. Seseorang dengan kepercayaan/ keyakinan diri yang tinggi sebagai memberikan hasil yang baik, orang-orang dengan keyakinan internal locus of control yang dianggap memiliki tingkat need of achievement yang tinggi (Abdel \&Halim, 1980; Spector, 1982 dalam Riipinen, 1994). Internal locus of control yang kuat akan berpengaruh terhadap need for achievement. Oleh karena itu, sangat mungkin bahwa baik internal locus of control yang tinggi dan need for achievement tinggi adalah karakteristik penting dari seseorang yang akan memulai usaha (Borland, 1975; Hansemark, 2003). Hasil penelitian ini berbeda dengan penelitian (Rahayu, 2010; Oktabriyantina. et $a l, 2014)$ tidak ada pengaruh internal locus of control dengan need for achievement siswa, need for achievement tumbuh karena adanya rangsangan dari lingkungan sekitar yang membuat individu untuk lebih bereksistensi di antara yang lainnya.

Hipotesis ketiga dalam penelitian ini adalah pengaruh social support terhadap need for achievement pada mahasiswa STIE YKPN. Hasil penelitian menunjukkan bahwa nilai $P<0,06$ dengan nilai signifikansi $5 \%$ hal tersebut menunjukkan bahwa variabel social support tidak berpengaruh pada variabel need for achievement mahasiswa STIE YKPN. Sarafino dalam Smet, (1994) mengatakan bahwa social support adalah kesenangan yang dirasakan, penghargaan akan kepedulian, atau bantuan yang diperoleh individu dari orang lain, di mana orang lain di sini dapat diartikan sebagai perorangan atau kelompok. Hal tersebut menunjukkan bahwa segala sesuatu yang ada di lingkungan menjadi dukungan sosial atau tidak, tergantung pada sejauh mana individu merasakan hal tersebut sebagai dukungan sosial. Para mahasiswa atau remaja akhir bukan hanya dukungan sosial yang dapat mempengaruhi tinggi rendahnya need for achievement namun dipengaruhi juga oleh beberapa faktor internal seperti usia, jenis kelamin, kemampuan, minat, harapan atau keyakinan (Tobing., et al., 2015). Hal ini sesuai dengan penelitian yang dilakukan oleh Rola F (2006) dalam (Tobing., et al., 2015) yang menyatakan bahwa konsep diri berhubungan dengan motivasi berprestasi pada remaja, apabila remaja merasa dirinya saat ini kurang berprestasi, namun dirinya merasa mampu untuk berprestasi maka 
remaja tersebut akan termotivasi sendiri untuk meningkatkan prestasinya.

Hipotesis ketiga dalam penelitian ini adalah pengaruh social support terhadap minat berwirausaha pada mahasiswa STIE YKPN. Hasil penelitian menunjukkan bahwa nilai $P<0,01$ dengan nilai signifikansi $5 \%$ hal tersebut menunjukkan bahwa variabel social support berpengaruh terhadap minat berwirausaha mahasiswa STIE YKPN. Hal ini sesuai penelitian yang dilakukan oleh Leon. et al, (2007) menyatakan dukungan sosial berpengaruh secara signifikan dan positif pada minat berwirausaha. Dukungan sosial ini berasal dari reference group (pasangan, orangtua, dan saudara) dan belonging group (teman, guru dan dosen). Social support mengacu pada fungsi dan kualitas hubungan sosial antar individu, seperti ketersediaan memberikan bantuan atau dukungan yang serius untuk seseorang. Hal ini terjadi melalui proses interaktif dan dapat berhubungan dengan rasa kewajiban dan persepsi timbal balik. Sebagai contoh, dukungan sosial dapat dianggap sebagai sumber daya yang disediakan oleh orang lain, seperti bantuan untuk mengatasi sebuah masalah (Srivastava \& Pant, 2015).

Hipotesis kelima dalam penelitian ini adalah pengaruh need for achievement terhadap minat berwirausaha pada mahasiswa STIE YKPN. Hasil penelitian menunjukkan bahwa nilai $P<0,01$ dengan nilai signifikansi $5 \%$ hal tersebut menunjukkan bahwa variabel need for achievement berpengaruh terhadap minat berwirausaha mahasiswa STIE YKPN. McClelland dalam Hansemark, (2003), kewirausahaan ditentukan oleh need for achievement. McClelland menegaskan bahwa need for achievement sebagai salah satu karakteristik kepribadian seseorang yang akan mendorong seseorang untuk memiliki minat kewirausahaan. Terdapat pengaruh positif antara need for achievement terhadap minat berwirausaha (Dwijayanti, 2015). Sengupta dan Debnath, (1994) dalam Dwijayanti (2015) dalam penelitiannya di India menemukan bahwa kebutuhan akan prestasi berpengaruh besar dalam tingkat kesuksesan seorang wirausaha. Lebih spesifik, kebutuhan akan prestasi juga dapat mendorong kemampuan pengambilan keputusan dan kecenderungan untuk mengambil resiko seorang wirausaha. Semakin tinggi kebutuhan akan prestasi seorang pengusaha/ wirausahawan akan mampu membuat keputusan yang tepat untuk tujuan hidupnya sendiri dan memiliki risk tolerance yang tinggi.

\section{SIMPULAN}

Penelitian ini menghasilkan temuan bahwa terdapat beberapa faktor yang mempengaruhi minat berwirausaha mahasiswa, yaitu internal locus of control, social support dan need for achievement. Internal locus of control berpengaruh signifikan terhadap minat berwirausaha mahasiswa STIE YKPN. Keyakinan diri mahasiswa akan keberhasilan yang akan diraih membuat mahasiswa semakin tertarik untuk berwirausaha. Internal locus of control juga berpengaruh signifikan terhadap need for achievement mahasiswa STIE YKPN. Keyakinan diri mahasiswa mendorong mahasiswa untuk mampu menguasai tantangan yang sulit, mendorong untuk mampu bersaing dengan lain, memenuhi standar yang tinggi dan memiliki keinginan 
untuk kompeten dalam berwirausaha. Social support berpengaruh signifikan terhadap minat berwirausaha. Tingginya social support mahasiswa, khususnya dorongan berwirausaha akan mendorong minat berwirausaha mahasiswa. Social support pada mahasiswa akan berpengaruh terhadap need for achievement, dengan adanya social support yang tinggi akan mendorong mahasiswa untuk semakin meraih kesuksesannya. Need for achievement berpengaruh signifikan terhadap minat berwirausaha. Mahasiswa yang memiliki keinginan untuk berhasil/ berprestasi, mereka akan berusaha untuk mencapai sasaran dan tujuannya dengan kemampuannya sendiri, sehingga hal tersebut akan mempengaruhi minat berwirausaha mahasiswa.

Penelitian tentang pengaruh internal locus of control, social support dan need for achievement terhadap intensi berwirausaha ini memiliki keterbatasan yaitu hanya dilakukan pada Sekolah Tinggi Ilmu Ekonomi (STIE) YKPN sehingga diharapkan untuk penelitian selanjutnya dilakukan pada beberapa perguruan tinggi lainnya agar hasilnya lebih representatif. Berdasarkan hasil penelitian dengan menggunakan PLS, ditemukan bahwa variabel need for achievement memediasi pengaruh internal locus of control dan social support terhadap minat berwirausaha, sehingga ada kemungkinan akan menghasilkan penelitian yang lebih baik jika dilakukan dengan menganalisis lebih lanjut peran need for achievement memediasi terhadap minat berwirausaha mahasiswa STIE YKPN.

Lebih lanjut hasil penelitian ini dapat membantu meningkatkan intensi berwirausaha mahasiswa, intensi berwirausaha mahasiswa dapat diukur melalui faktor internal locus of control, social support dan need for achievement. Peningkatan intensi berwirausaha mahasiswa dapat dilakukan dengan menerapkan proses pembelajaran di STIE YKPN dengan menggunakan model pembelajaran seperti pembelajaran kooperatif dan problem based learning untuk meningkatkan kepribadian internal locus of control, social support dan need for achievement mahasiswa sejak proses perkuliahan dimulai. Peningkatan intensi berwirausaha juga dapat dikembangkan dengan kunjungan ke tempat wirausaha yang sukses atau mengadakan seminar/ pelatihan motivasi kewirausahaan agar menambah semangat mahasiswa dalam minat berwirausaha daripada menjadi karyawan sebuah perusahaan.

\section{DAFTAR PUSTAKA}

Abdillah, W \& Jogiyanto, H. M. (2009). Konsep Dan Aplikasi PLS (Partial Least Square) Untuk Penelitian Empiris. Badan Penerbit Fakultas Ekonomi Dan Bisnis. Yogyakarta: UGM.

Adnyana, I.G.L.A. \& Purnami, N.M. (2016). Pengaruh Pendidikan Kewirausahaan, Self-Efficacy dan Locus of Control Pada Niat Berwirausaha. E-Jurnal Manajemen Unud, 5(2), 2016.

Hansemark, C.O. (2003). Need for Achievement, Locus of Control and The Prediction of Business Start-Ups: A Longitudinal Study. Journal of Economic Psychology, 24(3), 301-319.

Indari, N. \& Rostiani, R. (2008). Intensi Kewirausahaan Mahasiswa: Studi Perbandingan Antara Indonesia, Jepang 
dan Norwegia. Jurnal Ekonomika dan Bisnis Indonesia, 23(4).

Kautonen. Teemu, Seppo Luoto. (2008). Entrepreneurial Intention in the Third Age: The Impact of Career History. p. 9951007.

Lee-Kelley, L. (2006). Locus Of Control And Attitudes To Working In Virtual Teams. International Journal of Project Management, 24(3), 234-243.

Leon J.A, Descals, F.J, Dominguez, J.F. (2007). The Psychosocial Profile Of The University Entrepreneur. Journal of Psychology in Spain, 11(1), 72-84.

Moorhead, G. \& Griffin, R.W. (2013). Perilaku Organisasi. Jakarta: Salemba Empat.

Oktabriyantina, W., Sudarmanto, R.G., Pujiati. (2014). Hubungan Locus of Control dan Motivasi Berprestasi dengan Self Efficacy dan Minat Berwirausaha. Jurnal Edukasi Ekobis 2(1).

Ozaralli, N. \& Rivenburgh, N.K. (2016). Entrepreneurial Intention: Antecedents to Entrepreneurial Behavior In The U.S.A. And Turkey. Journal of Global Entrepreneurship Research, 6(3).

Parsa, K. (2011). A Model of Critical Psychological Factors Influencing Entrepreneurship Development in Iran Small and Medium-Scale Industries. European Journal of Scientific Research. 51(3), 383-395.

Ramayah, T. \& Harun. (2005). Entrepreneurial Intention Among the Student of University Sains Malaysia (USM). International Journal of Management and Entrepreneurship, 1: 820.

Rauch, A \& Frese, M. (2000). A Meta-Analysis on the Relationship between Business Owners' Personality Traits, Business Creation, and Success. European Journal of Work and Organizational Psychology
Riipinen, M. (1994). Extrinsic Occupational Needs and the Relationship Between Need for Achievement and Locus of Control. The Journal of Psychology 128(5).577-287.

Sarafino, E.P. (1994). Health Psychology (2.Ed). New York: Willey.

Sekaran, U. (2006). Research Method Business. Hermitage Publishing Services

Setiadi, U. (2008). Suatu Pemikiran Mengenai Pendekatan Kembali Antara Dunia Pendidikan S1 Manajemen Dengan Dunia Kerja. Prosiding Konferensi Merefleksi Domain Pendidikan Ekonomi dan Bisnis. Salatiga.

Smet, B .(1994). Psikologi Kesehatan. Jakarta: PT. Grasindo.

Taylor, S.E., Peplau, L.A., \& Sears, D.O. (1994). Social Psychology. New Jersey: Pretice Hall.

Toding, W.R.B., David, L., \& Pali, C. (2015). Hubungan Dukungan Sosial Dengan Motivasi Berprestasi Pada Mahasiswa Angkatan 2013 Fakultas Kedokteran Universitas Sam Ratulangi. Jurnal eBiomedik (eBm), 3(1).

Urban, B. \& Teise, H. (2015). Antecedents to Social Entrepreneurship Intentions: An Empirical Study In South Africa. Management Dynamics, 24(2).

Wiriani, W., Piatrini, S.Y \& Ardana. (2013). Efek Moderasi Locus of Control pada Hubungan Pelatihan dan Kinerja pada Bank Perkreditan Rakyat di Kabupaten Badung. Jurnal Ilmiah Akuntansi dan Bisnis, 8(2), 99-105.

Zain, Z.M., Akram, A.M., \& Ghani, E.K. (2010). Entrepreneurship Intention Among Malaysian Business Students. Canadian Social Science, 6(3), 34-44. 